\title{
Fagyási sérültek ellátása
}

\author{
DR. PATONAI ZOLTÁN, DR. PATCZAI BALÁZS, DR. WIEGAND NORBERT
}

\section{ÖSSZEFOGLALÁS}

A szerzők ismertetik a fagyási sérültek etiológiáját, patomechanizmusát, tüneteit, ellátásának lehetőségeit. A PTE KK Traumatológiai és Kézsebészeti Klinikán 2017. évben vették át a fagyási sérültek ellátását. A kezdeti tapasztalatok ösztönözték őket, hogy a „The University of Utah frostbite treatment algorithm” és a „Helsinki frostbite management protocol” alapján saját belső eljárási rendet alakítsanak ki. Végtagmentés céljából, számos nemzetközi cikk tanulmányozása után, hazánkban is törzskönyvezett, elérhető készítményekre alapozva dolgozták ki kezelési javaslatukat.

\section{Kulcsszavak: $\quad$ Fagyás; Fagyási sérülés; Thrombolysis}

Z. Patonai, B. Patczai, N. Wiegand: Treatment of frostbite injuries

The authors describe the etiology, pathomechanism, symptoms and treatment options of frostbite injury patients. In 2017, the Department of Traumatology and Hand Surgery of the University of Pécs took over the care of frostbite patients. Initial experience encouraged them to develop their own internal procedures based on "The University of Utah frostbite treatment algorithm" and "Helsinki frostbite management protocol". For the purpose of limb rescue, after studying several international articles, they developed their treatment proposal based on the products available in Hungary.

Keywords:

Cold temperature; Frosbite injuries; Thrombolysis; 


\section{BEVEZETÉS}

A fagyási sérülteket a szakirodalomban közölt kezelési eredmények alapján két nagy csoportba sorolhatjuk. Az egyik csoportba az egészséges extrémsportoló fiatal felnőttek, míg a másikba a rossz szociális körülmények között élők tartoznak. Az Egyesült Államokban, Oroszországban, Kanadában és a skandináv országokban mindkét csoportba tartozó beteganyagot megtaláljuk, mégis az eredményes kezelésről beszámoló cikkekben az egészséges, 17-30 éves katonák és hegymászók eseteit ismertetik $(7,11,17)$.

Hazánkban a földrajzi sajátosságok miatt a fagyás elsősorban a mélyszegénységben élő, polimorbid betegeket érinti. Sajnálatos módon e betegek körében a terápiás lehetőségeink korlátozottak, következményesen az eredményeink is szerényebbek.

Magyarországon a végtagokat érintő fagyási sérülések gyakorisága nem ismert. A KSH adatai szerint a „Túlságosan nagy hideg hatása” 2015. évben 168, míg 2016. évben 238 személy halálát okozta'. A haláloki statisztikából azonban nem lehet következtetni a fagyási sérülések gyakoriságára, és az ellátás alatt fellépő szövődmények számára. A végtagi fagyási sérültekkel kapcsolatos betegutak nem tisztázottak. Az ország egyes területein eltérő, hogy a beteget ki észleli először, a sebészeti kezelésig melyik osztályon ápolják és a mútéti beavatkozást hol végzik. Általánosan a végtagfagyott beteg az első megjelenése után lokális kezelésben (többnyire antibiotikum tartalmú kenőcs) részesül, majd a szövetelhalás demarkálódását követően az érintett végtagot amputálják.

A szakirodalomban számos közlemény jelent meg, amely ugyan szúk beteganyagon alkalmazott kezeléssel, de a végtag mentésére, rekonstrukciójára tesz kísérletet.

\section{ETIOLÓGIA}

A fagyási sérülés rizikója magas a gyermeknél (újszülött, csecsemő), az időseknél, a fertőzéses állapotokban, a cukorbetegeknél, a perifériás érbetegeknél, a pajzsmirigy betegeknél, a baleset (pl. csípőtáji sérülések) következtében kialakult mozgásképtelenség esetén, a pszichiátriai kórképekben, bizonyos reumatológiai (pl. athritis) és neurológiai betegségekben (pl. stroke) (13). A férfiaknál a fagyás incidenciája magasabb, mint a nőknél (24).

A szakirodalomban közölt betegek életkora: 30-49 év (31). A magyarországi beteganyagról pontos statisztikai adatok nincsenek. Betegeink átlagéletkora a szakirodalmi adatoknál magasabb.

\section{PATOMECHANIZMUS}

A bőr keringése $28-30{ }^{\circ} \mathrm{C}$ fokon (semleges hőmérséklet) percenként 200-250 ml. Amenynyiben a bőr hőmérséklete $15^{\circ} \mathrm{C}$ fokra csökken az áramló vér mennyisége - az érösszehúzódás miatt - percenként 20-50 ml lesz. A hőmérséklet csökkenésével az erek fokozatosan öszszehúzódnak, majd ez az állapot állandósulni látszik. A keringés teljes megszűnése előtt a szervezet igyekszik a szöveti perfúziót megtartani. A folyamat alapja, hogy a vasoconstrictio fokozatosan szúnik, az erek ismét kitágulnak, majd megint összehúzódnak. Így a termoreguláció, és a keringés is megtartott. A keringés megszűnéséig (köpenyhőmérséklet $0^{\circ} \mathrm{C}$ ) megfigyelhető ez a periodicitás.

A fagyás során a különböző szövetek a perfúziójukat igyekeznek megtartani. Elsőként a bőr és a bőralatti szövetek érintettek, majd a mélyebb rétegekben is fokozatosan csökken a hőmérséklet. A hideg sejtkárosító hatása direkt és indirekt mechanizmusok együttes eredménye.

A korai szakban intracellularisan jégkristályok jelennek meg, és a sejtekben protein- és lipid degradációs termékek halmozódnak fel. Ezzel párhuzamosan a vér viszkozitása nő, és a vasoconstrictio miatt pangás alakul ki. A kapillárisokban mikrothrombusok képződnek, majd a szöveti ischaemia fokozódik. Az idő előre haladtával a jégkristályok képződése extracellularisan is megfigyelhető. A kristályképződés az ozmotikus egyensúlyt felborítja és a sejtek dehidratálódásához vezet $(19,27)$.

${ }^{1}$ A KSH Statinfo haláloki statisztikáját 2017.10.05-én frissítették. A közölt adatok tekinthetőek a legfrissebb elérhető haláloki statisztikának. A halálokként a BNO XIX. főcsoportjába tartozó „Túlságosan nagy hideg hatása” (X31) alcsoportot jelölték meg. 
A „fagyás” és a „felolvadás” (freeze-thaw) periodikusan váltakozik, a folyamat progreszsziója lassú. A "felolvadás" a szövetek indirekt reperfúzis károsodásához és a degradációs termékek mediálta gyulladás kialakulásához vezet $(15,18,26)$.

A késői szakban a vascularis stasis, a vörösvértestek kicsapódása, a mikrothrombusok képződése és az érpermeabilitás fokozódása dominál. A károsodott és az ép szövetek között arteriovenosus shunt-ök nyílnak, a klinikai képet a thrombus indukálta gyulladás, a szöveti hypoxia és az anaerob metabolizmus uralja. A progresszív ischaemia miatt a szövetek károsodása a mélyebb rétegeket is érinti.

\section{TÜNETEK}

A végtagokon a fagyási sérülést három zónára osztjuk. Az érintett területen a szövetkárosodás distalisan, a koaguláció zónájában a legsúlyosabb (irreverzibilis). Előbbitől proximalisan található a stasis zónája. A károsodás itt is súlyos, de megfelelő kezelés mellett reverzibilisnek tekinthető. Efelett pedig a hyperaemia zónája van. A szövet érintettség itt a legenyhébb (8).
A fagyást a súlyossága szerint osztályozzuk (I. táblázat). A szakirodalomban, egy közleményben található stádium beosztás, amely az égési sérülteknél használtakhoz hasonló. Ez a Hennepin score, amely a végtag felszínének százalékos érintettsége alapján számolható érték. A publikáció szerzői szerint a módszer alkalmas a prognózis becslésre és a kezelés effektivitásnak számszerű mérésére (29). A felosztás bonyolultsága, és a gyakorlati alkalmazhatóságával kapcsolatos kételyeink miatt a részletes ismertetésétől eltekintünk.

A fagyás okozta csontszerkezeti eltérések az akut röntgenfelvételeken nem ábrázolódnak. Az expozíció után hetekkel, hónapokkal később a csontok mésztartalma csökken, periostitisre utaló csontszerkezeti eltérések láthatóak. Hónapokkal, évekkel a sérülés után acroosteolysisre utaló jeleket, az érintett csontok végein fokális sclerosist, aszimmetrikus arthrosist, apró periarticularis eróziókat és a gyermekeknél az epiphysis fuga feltöredezettségét, vagy korai záródása okozta deformitást láthatunk $(16,28)$. A fagyás okozta keringészavar kimutatására DSA vizsgálat, míg a csontok életképességének igazolására a 99mTc-HMDP csontszcintigráfia alkalmas.

\section{I. táblázat A fagyási sérülések osztályozása}

\begin{tabular}{|c|c|}
\hline & FROSTNIP* \\
\hline & $\begin{array}{c}\text { A bőr színe fehér, sensoros deficit van. A felmelegítés után a bőr } \\
\text { hyperaemiás. Analgesia helyett paresthesia észlelhető, mely néhány } \\
\text { hét alatt spontán szűnik. }\end{array}$ \\
\hline & FAGYÁS \\
\hline Grade I. & $\begin{array}{l}\text { A bőr rétegei részben érintettek. } \\
\text { A bőrön közvetlenül a fagyás után erythema, hyperaemia, ödaema } \\
\text { látható. 5-10 nappal később a hám foltokban leválik (desquamatio). } \\
\text { Necrosis és bulla képződés nincs. }\end{array}$ \\
\hline Grade II. & $\begin{array}{l}\text { A bőr minden rétege érintett. } \\
\text { A bőrön erythema, ödaema, desquamatio, víztiszta bennékű vesiculák } \\
\text { és hólyagok láthatóak. A bőr színe fekete. }\end{array}$ \\
\hline Grade III. & $\begin{array}{l}\text { A bőr minden rétegét és a bőr alatti szöveteket érinti. } \\
\text { A bőrön megtört vagy véres bennékű hólyagok, és a bőr elhalásának } \\
\text { jelei láthatóak. A bőr színe szürkés-fekete. }\end{array}$ \\
\hline Grade IV. & $\begin{array}{l}\text { A bőr minden rétegét, a bőr alatti szöveteket, az izmokat, az inakat és } \\
\text { a csontokat érinti. } \\
\text { Mérsékelt ödaema látható. A bőr színe először márványozott, sötét } \\
\text { vörös, vagy cianotikus, majd végül a bőr száraz, fekete színű lesz. }\end{array}$ \\
\hline
\end{tabular}

* magyar nyelvű szakirodalmi megfelelője nincs, frost: fagyás, nip: csípés. A fagyási sérülés legenyhébb formájának tekinthető. 


\section{KEZELÉS}

A fagyás modern kezelésének alapjául szolgáló elméleti és gyakorlati megfontolásokat 1983-ban a The Journal of Trauma hasábjain McCauley és munkatársai publikálták (25). A fagyási sérültek kezelésénél az elsődleges cél a szövetelhalás minimalizálása.

A kihúlt betegeket a kardiovaszkuláris instabilitás (rewarming shock) elkerülése végett lassan melegítjük. (3, 22, 30). A hypothermia pathomechanizmusa és terápiája a fagyásétól különbözik, részletesen terjedelmi korlátok miatt nem ismertetjük.

A fagyott végtagokat gyorsan, 40-42 $\mathrm{C}^{\circ}$ fokos $10 \%$ povidon-jód tartalmú vízfürdőben 15-30 perc alatt kell felmelegíteni. A végtagok gyors melegítése nem okoz keringés megingást.

A felmelegítés alatt parenteralis folyadékpótlás, $\mathrm{O} 2$ terápia, kombinált analgetikum (Ibuprofen $400 \mathrm{mg} 12$ óránként vagy $12 \mathrm{mg} / \mathrm{ttkg}$, kiegészítve félszintetikus opiát származékkal), vagy Ibuprofen és narkotikum együttes adása javasolt. Az Emberi Erőforrások Minisztériumának (EMMI) 2018. évi védőoltásokról szóló módszertani levelében foglaltaknak megfelelő tetanus profilaxist alkalmazunk.

A felmelegítés után a terápiás terv felállításához további vizsgálatok szükségesek. A fagyott végtagokról, és amennyiben törésre utaló fizikális jeleket észlelünk az érintett területekről röntgenfelvételt készítünk. Testüregi vérzés gyanúja esetén haemodinamikailag stabil betegeknél, közepes és nagy kockázatú koponya sérülteknél CT vizsgálat javasolt (6). A fizikális vizsgálatot laborral, rectalis digitális vizsgálattal, elektrokardiográfiával és metamfetamin fogyasztás kimutatásának céljából vizelet droggyorsteszttel (Innovacon ${ }^{\circledR}$ ) egészítjük ki. Napjainkban a vizelet droggyorsteszt gyakorlati jelentősége - részben a dizájner drogok elterjedése miatt - csökkent, azonban a metamfetamin gyors kimutatására költséghatékony megoldást jelent.

A terápiás terv felállításához a legtöbb információt az angiográfia (DSA) adja. A vizsgálat célja kettős, egyrészt a fagyás következtében kialakult perfúziós károsodás igazolása, másrészt a generalizált érbetegség miatt kialakult artériás occlusio kizárása. A DSA vizsgálat végzése javasolt a felmelegítést követően, a thrombolysis terápia befejezése után és a kezelés kezdetétől számított 2-3. napon.

A felmelegítés után 12 órával, amennyiben a bőr meleg tapintatú, az érzés megtartott, az ujjak színe rózsaszín és a distalisan elhelyezkedő bullákban a bennék víztiszta, akkor a prognózis jó. A DSA vizsgálat ebben az esetben nem indikált. A dohányzás tilalma és a végtag nyugalomba helyezése mellett a kezelést a II. táblázatban foglaltak szerint folytatjuk.

Angiográfia elvégzése indikált grade III-IV. fagyás és/vagy rossz prognózis esetén $(14,28)$. Rossz prognózisra utal, ha a bőr a felmelegítés után 12 órával is hideg tapintatú, az ujjak zsibbadnak, a bőr színe feketés vagy kék és a proximalis bullák bennéke véres. A DSA vizsgálat eredménye alapján a perfúzió megtartott, akkor a II. táblázat szerint kezeljük tovább a beteget. Perfúziós károsodás esetén, amennyiben nem kontraindikált (III. táblázat), aktivált szöveti plazminogén aktivátorral (tPa) thrombolysist végzünk. Gonzaga és munkatársai a thrombolysis relatív kontraindikációi közé sorolják a metamfetamin fogyasztását (14).

A Utah Medical Center fagyás managment algoritmusa szerint a thrombolyticus terápia bevezetéseként vasodilatator hatású papaverint adunk (érintett végtagonként $30 \mathrm{mg} / \mathrm{h}$ ), majd 2-4 mg aktivált szöveti plazminogén aktivátort (tPA) bolusban. A tPA fenntartó dózisa $1 \mathrm{mg} / \mathrm{h}$, amelyet legfeljebb a kezelést kezdetétól számított 12 óra hosszan adunk.

$\mathrm{Az}$ érintett végtagonként további 500 IU/h mennyiségben - APTT 50-70 s célérték eléréséig - frakcionálatlan heparint adunk $(5,28)$. A terápia alatt a keringést óránként Doppler ultrahanggal ellenőrizzük, 6 óránként labor vizsgálatot végzünk ( $\mathrm{Hgb}$, htc, tct, APTT, fibrinogén), az angiográfiát pedig 12 órával a kezelés kezdetét követően megismételjük $(5,28)$. A kezelést be kell fejezni, ha aktív vérzést észlelünk, ha a fibrinogén mennyisége $150 \mathrm{mg} / \mathrm{dl}$ alá csökkent, ha a Hgb mennyisége $7 \mathrm{~g} / \mathrm{dl}$ (Htc $<21,0 \%$ ) alá csökkent, ha a tct meny-

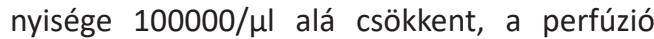
helyreállt, és ha a kezelés kezdete óta 48 óra telt el $(5,28)$.

A thrombolysis kontraindikációja, vagy a kezelés eredménytelensége esetén a felmelegítést követő 48 órán belül második vonalbeli szerként szintetikus prostaglandin 12 (Iloprost) 
adása javasolt. Az lloprostot első vonalbeli szerként használjuk, ha vasospasmusra utaló tüneteket észlelünk, de az angiográfián nem ábrázolódik thrombus okozta keringési zavar. Az lloprost kezdő dózisát $(0,5 \mathrm{ng} / \mathrm{tt} \mathrm{kg} / \mathrm{min}) 30$ percig adjuk, majd 30 perc alatt fokozatosan növelve érjük el a $2 \mathrm{ng} / \mathrm{ttkg} / \mathrm{min}$ dózist. $A$ kezelést napi 6 óra hosszan adjuk 2-3 napig. A kezelés alatt a beteget monitorozzuk (23). A szintetikus prostaciklin gátolja a thrombocyta aggregációt, növeli az endogén fibrinolyticus aktivitást, csökkenti a vascularis permeabilitást. A PGI ${ }^{2}$ vasodilatiót okoz, és a leukocyta akkumuláció és a tumor necrosis faktor felszabadulás gátlásával gyulladáscsökkentő hatása van. A kezelést kiegészíthetjük aszpirin adásával (9).

A kezelés kontraindikált terhességben, szoptatás alatt, akut vérzés esetén, instabil angina esetén, súlyos szívkoszorúér betegségben, az anamnézisben 6 hónapon belül myocardialis infarctus szerepel, akut vagy krónikus pangásos szívelégtelenségben (NYHA II--IV), súlyos arrhythmia és tüdőödéma gyanúja esetén (31).

A thrombolysis és a szintetikus prosztaciklin analóg kezelést követően a gyógyszeres terápiát a II. táblázatban foglaltak szerint 14-21 napig folytatjuk. A szakirodalmi adatok szerint
- a II. táblázatban említett kötszereken kívül - a lokális kezelésben az Aloe vera tartamú kenőcsöknek van terápiás effektivitása. Az Aloe vera ugyanis lokálisan csökkenti a thromboxán vasoconstriktív hatását $(20,26)$ továbbá baktericid és fungicid hatású (21).

A fagyási sérülés következménye lehet a krónikus fájdalom és a vasomotoros elégtelenség. A vasomotoros elégtelenség egy esetleges későbbi fagyási sérülésre predisponál. A Pentoxyphilin a krónikus panaszokat csökkenti.

A rendelkezésünkre álló kezelési lehetőségek ellenére az amputációt haladéktalanul el kell végezni, ha a fagyott végtag szeptikus állapot forrása. Ellenkező esetben sebészeti beavatkozást a demarkációt követően végezzünk, amely lehet bőrpótlás, lebeny átültetés vagy amputáció. A mútét tervezéséhez és az amputáció szintjének meghatározáshoz, amenynyiben elérhető a háromfázisú ${ }^{99 \mathrm{~m} T c-H M D P}$ csontszcintigráfia, annak elvégzése ajánlott. A vizsgálat sürgős amputáció esetén a felmelegítést követően 48 órán belül elvégezhető, egyébként a kezelés kezdetétől számított 2-8 nap között a leginformatívabb. A szcintigráfiával a csontok keringési zavarát, életképességét vizsgálhatjuk (2).

\section{II. táblázat A fagyáskezelés megtartott perfúzió esetén}

\begin{tabular}{|c|c|c|}
\hline \multicolumn{3}{|c|}{$\begin{array}{l}\text { bullák evakuációja } \\
\text { polyuretán és ezüst tartalmú kötszer }\end{array}$} \\
\hline Ibuprofen & 400 mg/12h v. 12 mg/ttkg & $\begin{array}{l}\text { analgetikus hatás, csökkenti a thromboxán } \\
\text { szintjét, gátolja a prosztaglandin szintézist, } \\
\text { gátolja a fvs migrációt és kemotaxist, tct } \\
\text { aggregáció gátló [32] }\end{array}$ \\
\hline Aszpirin & naponta $100 \mathrm{mg}$ & $\begin{array}{l}\text { fájdalomcsillapító, gyulladáscsökkentő, } \\
\text { thrombocyta aggregáció gátló }[4,32]\end{array}$ \\
\hline LMWH & $\begin{array}{l}\text { terápiás dózis 5-7 nap, } \\
\text { profilaktikus dózisban } 14 \text { napig }\end{array}$ & $\begin{array}{l}\text { antithrombotikus hatás, antikoaguláns } \\
\text { hatás [32] }\end{array}$ \\
\hline Pentoxyphilin & napi 1200 mg & $\begin{array}{l}\text { gátolja a vvt és vérlemezke aggregációt, } \\
\text { fibrinogén szintet csökkenti, vérviszkozítást } \\
\text { csökkenti, leukocyta aktiválódás gátló, } \\
\text { indirekt módon fokozza a mikrocirculációt, } \\
\text { gyulladáscsökkentő hatása }[1,4,32]\end{array}$ \\
\hline Cefalosporin* & $3 \times 1 \mathrm{gr}$ & \\
\hline
\end{tabular}

*grade III-IV, vagy a boka és csukló szintjét meghaladó fagyás esetén [23] 
III. táblázat Thrombolysis relativ és abszolút kontraindikációja

\begin{tabular}{|c|c|}
\hline \multicolumn{2}{|c|}{ THROMBOLYSIS KONTRAINDIKÁCIÓK } \\
\hline ABSZOLÚT & RELATÍV \\
\hline $\begin{array}{c}\text { fagyási sérülés után } 48 \mathrm{~h}< \\
\text { aktív vérzés } \\
\text { major trauma, fejsérülés, } 3 \text { héten belül mútét } \\
\text { korábban haemorrhagiás agyinfarctus } \\
6 \text { hónapon belül ischaemias agyinfarctus } \\
6 \text { hónapon belül subarachnoidalis vérzés } \\
\text { agydaganat } \\
\text { AV malformáció vagy kezeletlen aneurysma az } \\
\text { agyi ereken } \\
1 \text { hónapon belüli gastrointestinalis vérzés } \\
\text { aorta dissectio gyanúja } \\
\text { nem komprimálható helyekröl történt friss } \\
\text { biopszia (pl. máj) }\end{array}$ & $\begin{array}{c}6 \text { hónapon belül TIA } \\
\text { kezeletlen hypertonia (>180/110 Hgmm) } \\
\text { véralvadásgátló szedés ( } \mathrm{pl.} \text { warfarin) } \\
\text { gyomorfekély } \\
\text { krónikus májelégtelenség } \\
\text { terhesség, } 1 \text { hónapon belül szülés } \\
\text { infektív endocarditis } \\
\text { súlyos hypothermia } \\
\text { ismételt fagyási sérülése* } \\
\text { elhúzódó újraélesztés } \\
\text { compliance hiánya }\end{array}$ \\
\hline
\end{tabular}

*freeze-thaw-refreeze injury

\section{ÖSSZEGZÉS}

A fagyási sérültek ellátásban rendkívüli fontossággal bír a Sürgősségi Betegellátó Osztályokon (SBO) történő gyors diagnosztika és a szakszerű ellátás (1. ábra), ugyanis a fagyott végtagok lassú felmelegítése vagy felmelegedése esetén thrombusok képzőnek és a szövetelhalás fokozódik. A gyors ellátással (felmelegítés) a szövetelhalás mértéke csökkenthető, a végtag megmenthető $(3,4,26)$.

A szakirodalom megosztott a thrombolysis indikációjával kapcsolatban. Egyes szerzők a terápia nagy kockázata miatt csak a grade IV. fagyási sérülések kezelésére javasolják (10), míg mások a perfúziós zavar esetén, vagy a fagyás súlyossága ${ }^{2}$ alapján indikálják (14, 23). A felmelegítés után 24 órán belül végzett thrombolysis szignifikánsan csökkenti az amputáció incidenciáját (5). A szintetikus prostaciklin $\left(\mathrm{PGI}_{2}\right)$ kezelés kockázta a thrombolysis kockázatához képest alacsonyabb. Egyes szerzők emiatt a grade II-IV. fagyás esetén elsődleges kezelésként javasolják (10). A tPa és a prosztaciklin analógok adását intenzív terápiás háttér mellett thrombolysisben jártas személy végezze.

A tetanus injekció adása a módszertani levélnek megfelelően kötelező, azonban fagyásnál az alkalmazására vonatkozó evidencia alacsony. Az antibiotikum profilaxis hatása nem bizonyított $(4,16)$. Az antibiotikum terápiát a fertőzésre utaló tünetek esetén mindenképpen el kell indítani. A szakirodalom ajánlása szerint profilaktikusan antibiotikumot (cefalosporinok vagy penicillin származékok) csupán a mély (grade III-IV.) fagyási sérüléseknél, illetve a csukló és a boka ízület fölé terjedő fagyások esetén indítunk $(4,19)$. A fagyási sérültek kezelésben a lokálisan alkalmazott antibiotikum tartalmú kenőcsökre vonatkozóan a szakirodalom nem tesz ajánlást. Helyi alkalmazásra az Aloe vera tartalmú kenőcsőt javasolják, azonban a terápiára vonatkozó evidencia alacsony.

A throbolysis és a prosztaciklin analógok adását követően a beteg további obszervációja javasolt, mivel a kezelések következtében és/vagy a kórlefolyás miatt jelentkezhetnek akut beavatkozást igénylő szövődmények (pl. rhabdomyolysis, compartment szindróma). A fagyás után kialakult compartment szindróma esetén a szokásos módon járunk el, az izompólya behasításával az érintett izomrekeszek felszabadítását végezzük. A fagyási sérülés esetében is érvényesek az általános sebészeti

${ }^{2}$ A fagyási sérülés súlyos, ha egy ujj érintett és az ischaemiás jelek elérik vagy meghaladják a PIP vagy IP ízületet; vagy az ischaemiás jelek az ízületektől distalisan láthatóak, de több ujj érintett (23). 
elvek. Amennyiben a fagyott végtag szeptikus állapotot tart fenn, akkor annak okát meg kell szüntetni, a végtagot sürgősséggel amputálni kell.

Az amputáció optimális idejéről a szakirodalom egyértelműen nem nyilatkozik. Egyes szerzők szerint szöveti elhalás demarkálódásához a sérüléstől számított 3-6 hét, míg mások szerint 6-12 hét várakozás szükséges $(12,16)$. A sebészeti beavatkozás tervezésénél és kivitelezésnél szem előtt tartandó a cél, miszerint funkcionálisan elfogadható végtagot, vagy jól protetizálható csonkot kapjunk.

A fagyási sérülés gyógyulásának ideje hosszú, a fagyási sérültek követése legalább 12-24 hónapig ajánlott $(12,16)$. A sérültellátás hatékonyságának megítélése, és a szövődmények pontos feltérképezésének céljából „fagyási sérült" regiszter létrehozását javasoljuk.

Végtagi fagyási sérülések ellátása

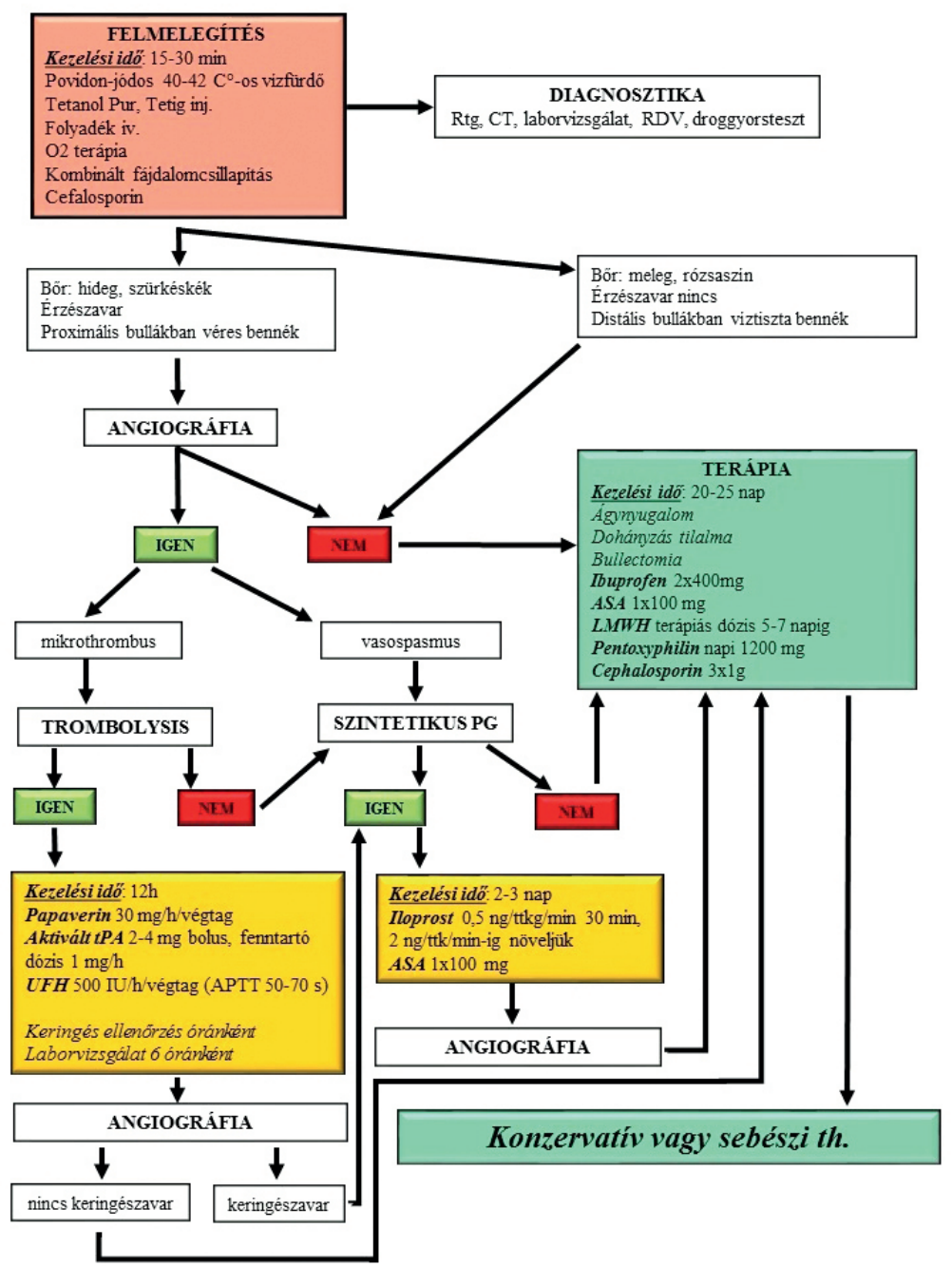

1. ábra

Fagyási sérültek ellátása 


\section{IRODALOM}

1. Al-Sudany N. K.: Treatment of primary perniosis with oral pentoxifylline (a double-blind placebo-controlled randomized therapeutic trial). Dermatol. Ther. 2016. 29. (4): 263-268. https://doi.org/10.1111/dth.12350

2. Arun R. J., Anurag J., Braj K., Aniruddha G. P.: Role of 99mTc MDP bone scan in delineation of ischaemic zone in cases of severe frostbite. Indian J. Nucl. Med. 2017. 32. (3): 203-207. https://doi.org/10.4103/ijnm.IJNM 1417

3. Biem J., Koehncke N., Classen D., Dosman J.: Out of the cold: management of hypothermia and frostbite. CMAJ. 2003.168. (3): 305-311.

4. Bilgiç S., Özkan H., Özenc S., Safaz I., Yildiz C.: Treating frostbite. Can. Fam. Physician. 2008. 54. (3): 361-363.

5. Bruen K. J., Ballard J. R., Morris S. E., Cochran A., Edelman L. S., Saffle J. R.: Reduction of the incidence of amputation in frostbite injury with thrombolytic therapy. Arch. Surg. 2007. 142. (6): 546-551. https://doi.org/10.1001/archsurg.142.6.546

6. Büki A., Barzó P., Demeter B., Kanizsai P., Ezer E., Tóth P., Horváth P., Varga C.: Baleseti agysérültek ellátásának irányelvei - 2017. [Guidelines for the treatment of traumatic brain injury - 2017]. Ideggyogy. Sz. 2017. 70. (7-8): 223-245. https://doi.org/10.18071/isz.70.0223

7. Cappaert A. T., Stone A. J., Castellani W. J., Krause A. B., Smith D., Stephens A. B.: National Athletic Trainers' Association position statement: environmental cold injuries. J. Athl. Train. 2008. 43. (6): 640-658. https://doi.orq/10.4085/1062-6050-43.6.640

8. Cauchy E., Chetaille E., Lefevre M., Kerelou E., Marsigny B.: The role of bone scanning in severe frostbite of the extremities: a retrospective study of 88 cases. Eur. J. Nucl. Med. 2000. 27. (5): 497-502. https://doi.org/10.1007/s002590050534

9. Cauchy E., Cheguillaume B., Chetaille E.: A controlled trial of a prostacyclin and rt-PA in the treatment of severe frostbite. N. Eng. J. Med. 2011. 364. (2): 189-190. https://doi.org/10.1056/NEJMc1000538

10. Cauchy E., Davis B. C., Pasquier M., Meyer F. E., Hackett H. P.: A new proposal for management of severe frostbite in the austere environment. Wilderness Environ. Med. 2016. 27. (1): 92-99. https://doi.org/10.1016/i.wem.2015.11.014

11. Ervasti O., Juopperi K., Kettunen P., Remes J., Rintamäki H., Latvala J., Pihlajaniemi R., Linna T., Hassi J.: The occurrence of frostbite and its risk factors in young men. Int. J. Circumpolar Health. 2004. 63. (1): 71-80. https://doi.org/10.3402/ijch.v63i1.17650

12. Eun-Kyung W., Jong W. L., Gi-Yeun H., Jang-Hyu K., Dong-Kook S., Jai-Ku C., Young-Chul J.: Proposed treatment protocol for frostbite: A Retrospective analysis of 17 cases based on a 3-year single-institution experience. Arch. Plast. Surg. 2013. 40. (5): 510-516. https://doi.org/10.5999/aps.2013.40.5.510

13. Golant A., Nord R. M., Paksima N., Posner M. A.: Cold exposure injuries to the extremities. J. Am. Acad. Orthop. Surg. 2008. 16. (12): 704-715. https://doi.org/10.5435/00124635-200812000-00003

14. Gonzaga T., Jenabzadeh K., Anderson P. C., Mohr J. W., Endorf W. F., Ahrenholz H. D.: Use of intra-arterial thrombolytic therapy for acute treatment of frostbite in 62 patients with review of thrombolytic therapy in frostbite. J. Burn Care Res. 2016. 37. (4): 323-334. https://doi.org/10.1097/BCR.0000000000000245

15. Gruys E., Toussaint M. J. M., Niewold T. A., Koopmans S. J.: Acute phase reaction and acute phase proteins. J. Zhejiang Univ. Sci. B. 2005. 6. (11): 1045-1056. https://doi.org/10.1631/izus.2005.B1045

16. Handford C., Buxton P., Russell K., Imray E. A. C., McIntosh E. S., Freer L., Cochran A., Imray H. E. C.: Frostbite: a practical approach to hospital management. Extrem. Physiol. Med. 2014. 3. (7): 1-10. https://doi.org/10.1186/2046-7648-3-7

17. Hashmi M. A., Rashid M., Haleem A., Bokhari S. A., Hussain T.: Frostbite: epidemiology at high altitude in the Karakoram mountains. Ann. R. Coll. Surg. Engl. 1998. 80. (2): 91-95.

18. Hideki M., Yukiko H., Isamu T., Takao Y., Yasushi S.: LIGHT, a member of the tumor necrosis factor ligand superfamily, prevents tumor necrosis factor- $\alpha$-mediated human primary hepatocyte apoptosis, but not fas-mediated apoptosis. J. Biol. Chem. 2002. 277. (51): 50054-50061. https://doi.org/10.1074/jbc.M206562200

19. Hutchison R. L.: Frostbite of the hand. J. Hand. Surg. Am. 2014. 39. (9): 1863-1868. https://doi.org/10.1016/j.jhsa.2014.01.035

20. Jurkovich G. J.: Environmental cold-induced injury. Surg. Clin. North. Am. 2007. 87. (1): $247-267$. https://doi.org/10.1016/j.suc.2006.10.003

21. Klein A. D., Penneys N. S.: Aloe vera. J. Am. Acad. Dermatol. $1988 . \quad 18 . \quad$ (4): 714-720. https://doi.org/10.1016/S0190-9622(88)70095-X

22. Kondratiev T. V., Wold R. M., Aasum E., Tveita T.: Myocardial mechanical dysfunction and calcium overload following rewarming from experimental hypothermia in vivo. Cryobiology. 2008. 56. (1): $15-21$. https://doi.org/10.1016/i.cryobiol.2007.09.005

23. Lindford A., Valtonen J., Hult M., Kavola H., Lappalainen K., Lassila R., Aho P., Vuola J.: The evolution of the Helsinki frostbite management protocol. Burns. 2017. 43. (7): 1455-1463. https://doi.org/10.1016/i.burns.2017.04.016

24. Mäkinen T. M., Jokelainen J., Näyhä S., Laatikainen T., Jousilahti P., Hassi J.: Occurrence of frostbite in the general population--work-related and individual factors. Scand. J. Work. Environ. Health. 2009. 35. (5): $384-393$. https://doi.org/10.5271/sjweh.1349

25. McCauley R. L., Hing D. N., Robson M. C., Heggers J. P.: Frostbite injuries: A rational approach based on the pathophysiology. J. Trauma. 1983. 23. (2): 143-147. https://doi.org/10.1097/00005373-198302000-00013

26. McCauley R. L., Heggers J. P., Robson M. C.: Frostbite. Methods to minimize tissue loss. Postgrad. Med. 1990. 88. (8): 67-68, 73-77. https://doi.org/10.1080/00325481.1990.11704769 
27. McIntosh S. E., Opacic M., Freer L., Grissom C. K., Auerbach P. S., Rodway G. W., Cochran A., Giesbrecht G. G., McDevitt M., Imray C. H., Johnson E. L., Dow J., Hackett P. H.: Wilderness Medical Society practice guidelines for the prevention and treatment of frostbite: 2014 update. Wilderness Environ. Med. 2014. 25. (4): 43-54. https://doi.org/10.1016/i.wem.2014.09.001

28. Millet D. J., Brown J. K. R., Levi B., Kraft T. C., Jacobson A. J., Gross D. M., Wong K. K.: Frostbite: Spectrum of imaging findings and guidelines for management. Radiograpics. 2016. 36. (7): 2154-2169. https://doi.org/10.1148/rg.2016160045

29. Nygaard R. M., Whitley A. B., Fey R. M., Wagner A. L.: The Hennepin Score: Quantification of Frostbite Management Efficacy. J. Burn Care Res. 2016. 37. (4): 317-322. https://doi.org/10.1097/BCR.0000000000000277

30. Tveita T.: Rewarming from hypothermia. Newer aspects on the pathophysiology of rewarming shock. Int. J. Circumpolar Health. 2000. 59. (3-4): 260-266.

31. Valnicek S. M., Chasmar L. R., Clapson J. B.: Frostbite in the prairies: a 12-year review. Plast. Reconstr. Surg. 1993. 92. (4): 633-641. https://doi.org/10.1097/00006534-199309001-00012

\section{Dr. Patonai Zoltán}

PTE KK Traumatológiai és Kézsebészeti Klinika

E-mail: patonai.zoltan@pte.hu 
